\title{
ВПЛИВ БІОЛОГІЧНОГО ПОДРАЗНИКА НА ВМІСТ ФЕРУМУ В КРОВІ ЦУЦЕНЯТ
}

М. Анфьорова, М. Брошков, О. Данчук

Одеський державний аграрний університет

Будь-яка форма імунної активачії впливає на витрату заліза в організмі $i$, як правило, призводить до зменшення вмісту заліза в плазмі крові. Метою наших досліджень було встановлення рівня Феруму в крові иуценят за введення біологічного подразника. В якості біологічного подразника використовували полівалентну вакцину (DHPPi, Nobivac). Проведеними дослідженнями встановлено, щуо вміст Феруму в крові иуценят до дії біологічного подразника

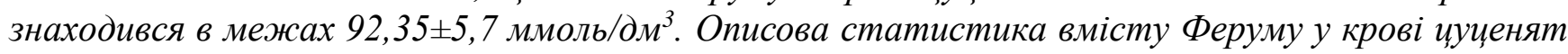
через чотири тижні після дії біологічного подразника свідчить, щзо у 95 \% иуценят вміст металу в крові знаходиться в межах 13,5-19,8 ммоль/дм' ${ }^{3}$, причому у $68 \%$ тварин його вміст не відрізняється більше ніж на 2,8 ммоль/дм . Показник стандартної похибки середньої величини $(S E=1,2)$ вказує на істотне зменшення варіабельності (у декілька разів) вмісту металу в межах популяиії у кіниі дослідного періоду.

Ключові слова: иуценята, Ферум, біологічний подразник, імунітет.

Основними факторами, що характеризують стан оксигенотранспортної функції крові $\epsilon$ кількість еритроцитів, вміст гемоглобіну та наявність необхідних пластичних ресурсів для їх утворення, зокрема - Феруму [1].

Оскільки залізо необхідне для життя, але воно також токсичне в надлишку, у ссавців існує складна система його регулювання та доступності. Дивно, але ссавці не мають визначеного механізму виведення заліза [2]. Дослідженнями встановлено зниження концентрації гемоглобіну та еритроцитів у цуценят від народження до 60-ти денного віку майже в два рази [3]. Крім того, практично будь-яка форма імунної активації впливає на витрату заліза в організмі i, як правило, призводить до зменшення вмісту заліза в плазмі крові (гіпоферремія) та його розділення в системі мононуклеарів (MPS) [4]. Багатогранна роль гомеостазу заліза в патогенезі інфекцій із субклітинними агентами, такими як віруси та пріони, висвітлюється іншими оглядами $[5,6,7]$. Отже роль Феруму в крові цуценя, особливо в критичний період, а саме за введення біологічного подразника є актуальним і потребує досліджень.

Метою наших досліджень було встановлення рівня Феруму в крові цуценят за введення біологічного подразника.

Матеріали і методи. Перед забором крові, тварин утримували від прийому їжі 8 годин. Об'єктом досліджень були шість цуценят породи Ретривер. В якості біологічного подразника використовували полівалентну вакцину (DHPPi, Nobivac). Вводили двічі підшкірно з інтервалом 14 днів. Кров відбирали з ліктьової вени тричі з інтервалом 14 днів. Для дослідження вмісту заліза відбирали цільну кров у пробірки з активатором згортання крові $\left(\mathrm{SiO}_{2}\right)$, сироватка була ретельно відокремлена від формених елементів крові не пізніше, ніж через 1 годину після взяття крові. Визначення вмісту заліза в сироватці крові проводили на біохімічному аналізаторі Evolution 3000 (Італія) з використанням тест-системи для визначення концентрації заліза фірми «СпайнЛаб» (Україна).

Результати власних досліджень. Проведеними дослідженнями встановлено, що вміст Феруму в крові цуценят до дії біологічного подразника знаходився в межах $92,35 \pm 5,7$ ммоль/дм ${ }^{3}$. В генеральній сукупності показники вмісту металу розподілені за законом нормального розприділення, так, як вибіркові значення середнього відрізняються незначно, а мінімальне $\mathrm{i}$ максимальне значення рівновіддалені від середнього.

Показник довірчого інтервалу (CI) дозволяе 3 певною ймовірністю $(\alpha=0,05$, або $95 \%)$ дозволяє оцінити значення зазначеного показника у всій популяції тварин. Оцінюючи зазначений розмір вибірки $(\mathrm{n}=6)$ ми можемо достовірно стверджувати, що у $95 \%$ цуценят місячного віку породи Лабрадор вміст Феруму в крові знаходиться в межах 76,5-110,6 ммоль/дм³. Тоді, як у 68 $\%$ всіх тварин вміст цього металу не відрізнявся більше ніж на 11,4 ммоль/дм ${ }^{3}$. Встановлено 
широкі коливання у вибірці показників вмісту Феруму в крові корів, що витікає з значних показників дисперсії $\left(\mathrm{S}^{2}\right.$, мінливості змінної). Поряд з цим, оцінка можливої мінливості між значенням середнього показника у вибірці та середнім значенням в усій популяції вказує на меншу варіабельність вмісту Феруму в крові всередині популяції (показник стандартної похибки середньої величини - $\mathrm{SE}=4,7)$.

Таблиця 1. Статистична оцінка вмісту Феруму (ммоль/дм³) у крові цуценят за дії біологічного подразника $(\mathrm{n}=6)$

\begin{tabular}{|c|c|c|c|}
\hline \multirow{2}{*}{$\begin{array}{c}\text { Статистичні } \\
\text { показники }\end{array}$} & $\begin{array}{c}|c| \\
\text { До дії біологічного } \\
\text { подразника }\end{array}$ & Через 14 днів & Через 28 днів \\
\hline $\mathrm{M}$ & 92,4 & 38,1 & 17,2 \\
\hline $\mathrm{m}$ & 5,7 & 7,3 & $\mathrm{p}>0,001$ \\
\hline $\mathrm{p}$ & - & $\mathrm{p}>0,001$ & 13,5 \\
\hline Min. & 76,5 & 22,8 & 19,8 \\
\hline Max. & 110,6 & 61,6 & 1,2 \\
\hline $\mathrm{SE}$ & 4,7 & 5,9 & 2,8 \\
\hline $\mathrm{S}$ & 11,4 & 14,5 & 8,0 \\
\hline $\mathrm{S}$ & 130,2 & 210,9 & 3,0 \\
\hline $\mathrm{CI}$ & 12,0 & 15,2 & \\
\hline
\end{tabular}

Примітка. Достовірні різниці (р) з показником до дії подразника.

За дії біологічного подразника встановлено істотне зменшення вмісту Феруму в сироватці крові цуценят (протягом 2 тижнів у 2,4 раза; $\mathrm{p}>0,001$ ). Причому варіабельність вмісту металу в крові всередині популяції збільшується $(\mathrm{SE}=5,9)$, що вказує на певну відмінність впливу подразника на вміст металу в крові цуценят у популяції, це підтверджується збільшенням показника мінливості змінної $\left(\mathrm{S}^{2}=210,9\right)$. Так, у $95 \%$ цуценят через два тижні після дії біологічного подразника вміст металу в крові знаходиться в межах 22,8-61,6 ммоль/дм ${ }^{3}$, а у 68 \% тварин його вміст не відрізняється більше ніж на 14,5 ммоль/дм ${ }^{3}$.

В подальшому з другого до четвертого тижня після дії біологічного подразника вміст Феруму в крові цуценят продовжує знижуватись (у 2,2 раза;. $\mathrm{p}>0,001)$. Описова статистика вмісту Феруму у крові цуценят через чотири тижні після дії біологічного подразника свідчить, що у $95 \%$ цуценят вміст металу в крові знаходиться в межах 13,5-19,8 ммоль/дм ${ }^{3}$, причому у $68 \%$ тварин його вміст не відрізняється більше ніж на 2,8 ммоль/дм³. Показник стандартної похибки середньої величини $(\mathrm{SE}=1,2)$ вказує на істотне зменшення варіабельності (у декілька разів) вмісту металу в середині популяції у кінці дослідного періоду.

Таким чином, отримано нові наукові дані щодо динаміки вмісту Феруму в крові цуценят місячного віку породи Лабрадор за дії біологічного подразника. Показано істотне зменшення вмісту металу поряд із збільшення варіабельності його вмісту протягом двох тижнів після дії біологічного подразника. Протягом адаптації тварин 3 другого до четвертого тижня після дії біологічного подразника вміст Феруму в крові цуценят продовжує знижуватись, що може призвести до розвитку анемічного стану та гіпоксії.

Наші дослідження потребують подальших досліджень з встановленням рівня біологічних речовин в крові цуценя, що приймають участь в регуляторних механізмах Феруму.

Висновки. Імунні реакції в організмі за дії біологічного подразника пов'язані з витратою достатньої кількості Феруму, про, що свідчить його зменшення майже в 5,4 рази протягом 28 днів.

\section{Список використаних джерел:}

1. Developmental plasticity of red blood cell homeostasis / M. Golub та ін. // American journal of hematology. 2014. № 89 (5). C.459-466 URL: https://doi.org/10.1002/ajh.23666

2. Nairz M, Weiss G. Iron in infection and immunity. Mol Aspects Med. 2020, 75:100864. DOI: https://doi.org/10.1016/j.mam.2020.100864.

3. Дмитренко Н. І. Морфологічний склад крові цуценят до 60-ти денного віку. Проблеми зооінженерії та ветеринарної медицини: Зб. Наук. праць Харківської державної зооветеринарної 
академії. Х.: РВВ ХДЗВА., 2013. 27 ч. 2 «Ветеринарні науки». С. 17-20. URL: http://dspace.pdaa.edu.ua:8080/handle/123456789/1492

4. Haschka D., Hoffmann A., Weiss G. Iron in immune cell function and host defense. Seminars in Cell \& Developmental Biology. 2020. DOI: https://doi.org/10.1016/j.semcdb.2020.12.005.

5. Drakesmith H., Prentice A. Viral infection and iron metabolism. Nat Rev Microbiol. 2008. 6. P.541-552. DOI: https://doi.org/10.1038/nrmicro1930

6. Schmidt S.M. The role of iron in viral infections. Front Biosci. Landmark, 2020. 25. P.893-911.

7. Wessling-Resnick M. Crossing the Iron Gate: Why and How Transferrin Receptors Mediate Viral Entry. Апnи Rev Nutr, 2018. 38. P.431-458. DOI: https://doi.org/10.1146/annurev-nutr-082117051749.

\section{INFLUENCE OF A BIOLOGICAL STIMULUS ON THE FERUM CONTENT IN THE PUPPIES' BLOOD}

M. Anforova, M. Broshkov, O. Danchuk

Any form of immune activation affects the consumption of Ferum in the body and, as usual, leads to a decrease of the Ferum content in the blood plasma. The aim of our research was to determine the level of Ferum in the blood of puppies under the conditions of introduction the biological stimulus. A polyvalent vaccine (DHPPi, Nobivac) was used as a biological stimulus. The studies have established that Ferum content in the blood of puppies before influence of the biological stimulus was within 92.35 $\pm 5.7 \mathrm{mmol} / \mathrm{dm} 3$. Descriptive statistics of the Ferum content in the blood of puppies four weeks after exposure of biological stimulus indicates that in $95 \%$ of puppies the metal content in the blood is in the range of 13.5-19.8 mmol / dm3, and in 68\% of animals its content does not differ by more than by 2.8 $\mathrm{mmol} / \mathrm{dm} 3$. The standard error of the mean $(S E=1.2)$ indicates a significant decrease in the variability (several times) of the metal content in the population at the end of the study period.

Keywords: puppies, Ferum, biological stimulus, immunity.

\section{ВЛИЯНИЕ БИОЛОГИЧЕСКОГО РАЗДРАЖИТЕЛЯ НА СОДЕРЖАНИЕ ЖЕЛЕЗА В КРОВИ ЩЕНКОВ}

М. Анфёрова, М. Брошков, А. Данчук

Любая форма иммунной активаџии влияет на расход железа в организме и, как правило, приводит к уменьшению содержания железа в плазме крови. Целью наших исследований было установление уровня железа в крови щенков в условиях введения биологического раздражителя. $B$ качестве биологического раздражителя использовали поливалентную вакцину (DHPPi, Nobivac). Проведенныли исследованиями установлено, что содержание железа в крови щенков до действия биологического раздражителя находился в пределах 92,35 \pm 5,7 ммоль / дм3. Описательная статистика содержания железа в крови щенков через четыре недели после воздействия биологического раздражителя свидетельствует, что у 95\% щенков содержание металла в крови находится в пределах 13,5-19,8 ммоль / дм3, причем у 68\% животных его содержание не отличается более чем на 2,8 ммоль / дм3. Показатель стандартной погрешности средней величинь $(S E=1,2)$ указывает на существенное уменьшение вариабельности (в несколько раз) содержания металла в популяции в конце исследовательского периода.

Ключевые слова: щеенки, железо, биологический раздражитель, иммунитет. 